\title{
Early Screening of Some Kurdistan Wheat (Triticum aestivum L.) Cultivars under Drought Stress
}

\author{
Nariman S. Ahmad ${ }^{1}$, Shadia H. S. Kareem ${ }^{1}$, Kamil M. Mustafa ${ }^{1}$ \& Dastan A. Ahmad \\ ${ }^{1}$ Crop Science Department, Faculty of Agricultural Sciences, University of Sulaimani, Kurdistan, Iraq \\ Correspondence: Nariman S. Ahmad, Faculty of Agricultural Sciences, Sulaimani University, Sulaimani, \\ Kurdistan 46001, Iraq. Tel: 964-(0)770-143-4873. E-mail: nariman.ahmad@univsul.edu.iq
}

Received: October 31, 2016

Accepted: December 7, 2016

Online Published: January 15, 2017

doi:10.5539/jas.v9n2p88

URL: http://dx.doi.org/10.5539/jas.v9n2p88

\begin{abstract}
Due to the rapid climatic change drought becomes abiotic constraint globally. A factorial laboratory experiment was designed with CRD to evaluate the effects of kernel priming on wheat cultivars under induced drought stress. Seven common wheat cultivars in Kurdistan (Adana, Maxipak, Sham4, Sham6, Aras, Azadi and Rizgari) were tested under different negative osmotic solutions $(0,-0.5,-1$ and $-1.5 \mathrm{Mpa})$, using Polyethylene glycol (PEG-6000). Among different cultivars Azadi exhibited better survival at high levels of drought stress for germination and its related traits. It also revealed high performance for shoot growth under the water stress, which was affirmed by the principal component analysis and cluster analysis. The superiority of this cultivar might be refer to exposing of this genotype to natural selection for a long duration under semiarid conditions of the local environment. Rizgari also had better performance mostly for the seedling characteristics, being a suitable cultivar for the late induced drought. The other cultivars had an intermediate response to the induced drought stress. This method could assist the plant breeder for rapid detection of drought tolerant genotypes in a large population with the reduced cost and labor compared to field trials.
\end{abstract}

Keywords: wheat cultivars, drought stress, polyethylene glycol, germination, cluster analysis

\section{Introduction}

Drought stress is considered to be one of the major abiotic constraints worldwide that limits the growth and productivity of crop plants (Jain, Mittal, \& Gadre, 2013). Plants are varied in their capacity to adjust their metabolism and growth. They can tolerate the particular abiotic stress by establishing a metabolic homeostasis being in less stress for this condition. While the sensitive plants are unable to launch metabolic homeostasis that results in the growth and yield reduction, ending by the plant death (Jogaiah, Govind, \& Tran, 2013). Under rain-fed conditions, water shortage is a severe limiting factor for germination and seedling establishment. These stages are extremely important to determine the growing period and the yield of crops (Khakwani et al., 2011). Among different plant species, wheat is one of the major crops worldwide, it accounts for about $20 \%$ of the human food supply. Wheat consumption has increased by $5 \%$ a year in the developing countries for nearly the last 70 years (Marmar, Baenziger, Dweikat, \& El Hussein, 2013). The global production of wheat is significantly affected by the climate change and water scarcity in the grown environment (Al-Ghamdi, 2009; Bano, Ullah, \& Nosheen, 2012). Water shortage at germination and seedling stage is among the factors to influence the yield of wheat crop (Noorka \& Khaliq, 2007). The study programs of inducing drought tolerance in wheat should address the problem in a multi-disciplinary approach (Marmar et al., 2013). Selection of physiological traits associated with the drought tolerance is essentially enhanced to increase the efficiency of selection (Ciucă, Bănică, David, \& Săulescu, 2010). Early screening as a physiological dissection of drought tolerance is one of the approaches to assist plant breeder in rapid detection of suitable genotype to be involved in the next breeding program.

To raise the productivity of wheat crop, it is crucial to identify the genotype that tolerate higher level of drought. This can be obtained by exploring maximum genetic potential from available wheat germplasm (Chachar et al., 2014). Screening for drought tolerance based on the field trials is costly and time-consuming, in addition to the typical condition required to express their effective genes responsible for the studied characteristics. Therefore, preliminary screening methods are commanded for the field criteria (Kim, Yun, H. K. Park, \& M. S. Park, 2001). Identifying the drought tolerant wheat genotypes at germination and seedling growth stage under low osmotic potential is practiced as a reliable physiological indicator by the researchers (Chachar et al., 2016). Hence, the 
investigation of water stress based on the germination of different varieties is a forward step to identify the most tolerant genotype (s) under drought stress. Selection for drought tolerance at germination and the early seedling stage is frequently accomplished using simulated drought induced by chemicals like polyethylene glycol (PEG6000). It imposes water stress under in vitro conditions that maintains a uniform water potential throughout an experimental period, whereby a large set of genotypes can be screen accurately (Manoj \& Uday, 2007).

The advantage of using Poly Ethylene Glycol (PEG) compared to others osmotic solutions is that due to the high molecular weight (6000-8000) PEG cannot enter the plant cells, instead, the water is withdrawn from the cell and cell wall without affecting or hurting the cell structure (Van den Berg \& Zeng, 2006). While other osmotic solutions of low molecular weight could be toxic to plant as they are easily be taken by the plant (Hamza, 2012). Polyethylene glycol molecules are known to be inert, no-ionic, virtually impermeable to cell membranes and can induce uniform water stress without causing direct physiological damage (Kulkarni \& Deshpande, 2005). PEG as a drought stress causing factor can reduce water potential, resulting in the growth reduction of germinated seeds and seedling (Zhu, Kang, Tan, \& Xu, 2006).

The objective of this study was to evaluate the wheat cultivars for drought resistance at germination and early growth stage, utilizing PEG-6000 as an osmoticum to induce different levels of stress conditions to allow rapid screening for the most tolerant wheat genotypes to water stress.

\section{Methods}

\subsection{Plant Materials}

The experimental material was consisted of seven wheat cultivars (Table 1). They represented the commercial cultivars of common wheat in Kurdistan region. They were obtained from Bakrajo research station of Sulaimani and Erbil research station.

Table 1. Names and the sources of seven wheat cultivars used in the study

\begin{tabular}{|c|c|c|c|}
\hline No. & Name & Pedigree/origin & Source \\
\hline $\mathrm{G}_{1}$ & Adana & Turkey & \multirow{5}{*}{$\begin{array}{l}\text { Bakrajo research Station, } \\
\text { Sulaimani }\end{array}$} \\
\hline $\mathrm{G}_{2}$ & Maxipak & $\begin{array}{l}\text { (Frontana } \times \text { Kenya } 58-\text { New thatch/Norin } 10 \text { Brevor }) \times \text { Gabo } 55 \text {. } \\
\text { Pakistan. Local for Iraq }\end{array}$ & \\
\hline $\mathrm{G}_{3}$ & Sham4 & ICARDA & \\
\hline $\mathrm{G}_{4}$ & Sham6 & $\begin{array}{l}\text { PLC “S”- Ruff "S" } \times \text { Gta “S”- RTTE } \\
\text { Cm-12904-1M-3M-1Y-1Y-OSK-OAP. ICARDA }\end{array}$ & \\
\hline $\mathrm{G}_{5}$ & Aras & $\begin{array}{l}(\text { Sonora } 64 \times \text { Lerma Rojoo } 64) \times \text { Sentaclena. Mexico. Local For } \\
\text { Kurdistan region }\end{array}$ & \\
\hline $\mathrm{G}_{6}$ & Azadi & Local For Kurdistan region & \multirow{2}{*}{ Erbil Research Station } \\
\hline $\mathrm{G}_{7}$ & Rizgari & Local For Kurdistan region & \\
\hline
\end{tabular}

\subsection{Osmotic Stress Experiment}

A laboratory experiment was conducted to estimate the drought stress of seven wheat cultivars. The experiment was laid out in completely randomized design (CRD) with two factors: genotypes and water stresses. Four osmotic solutions (including distilled water) were applied during the germination period on the common wheat cultivars with three replicates, using Poly Ethylene Glycol (PEG) of molecular weight 6000 . The levels of negative osmotic solutions were prepared for the potentials of $0,-0.5,-1$ and $-1.5 \mathrm{Mpa}(0,-5,-10$ and -15 bar $)$ by dissolving separately calculated amounts of PEG 6000 in distilled water (0, 17.0, 21.9, 25.3g PEG 6000/100 ml), respectively, at $30^{\circ} \mathrm{C}$.

Kernels were surface sterilized with ethanol $70 \%$ for 15 min. Residual ethanol was removed by thorough washing with sterilized distilled water. Twenty grains from each variety with three replicates were placed in Petri dish (90 mm diameter) for all treatments. Two layers of Whatman filter paper were used and moistened with 10 $\mathrm{ml}$ of distilled water and the Petri dishes were placed in a dark incubator for 24 hours for an "imbibition period" at $25{ }^{\circ} \mathrm{C}$. Five $\mathrm{ml}$ of designated treatment solution was applied every three days into each petri dish after thorough washing and draining the previous left solution. The Petri dishes were kept under laboratory condition in an incubator (M $7040 \mathrm{R}$ Electro.mag) at $25 \pm 2{ }^{\circ} \mathrm{C}$ for 12 days. 
The germinated seeds were counted daily for the experiment duration, started from the second day after sowing. Seeds were considered germinated when they exhibited radicle extension more than $2 \mathrm{~mm}$. The following characteristics were measured:

Germination percentage (\%): Counted after 4, 8 and 12 days with some modifications according to International Seed Testing Association (ISTA, 1993).

Germination $\%=($ The number of germinated seeds until the i day/total number of seeds $) \times 100$

Mean Daily Germination (MDG): It is an index of daily germination speed determined by the following equation (Ellis \& Roberts, 1981):

$$
\text { Mean Daily Germination }(\mathrm{MDG})=\text { FGP/d }
$$

Where, FGP: final germination percentage (Viability), d: day(s) spent from the first to final germination.

$>$ Coefficient of velocity of germination $(\mathrm{CVG})$ : This index is the velocity and acceleration of seed germination, gives an indication of the germination rapidity. It increased when the number of germinated seeds increases and the time required for germination decreases. It was calculated by the following equation (Kader \& Jutzi, 2004):

$$
\left.\operatorname{CVG}\left(\% \cdot \mathrm{d}^{-1}\right)=100 \times \Sigma \mathrm{Ni} / \Sigma(\mathrm{NiTi})\right)
$$

Where, $\mathrm{N}$ is the percentage of germinated seed in day $\mathrm{i}$, and $\mathrm{Ti}$ is the sequence of day from sowing seed.

$>$ Germination rate index (GRI): Reflects the percentage of germination on each day for the germination period. Higher GRI values indicate higher and faster germination. It was calculated by the following equation (Kader, 2005):

$$
\text { GRI }\left(\% \cdot d^{-1}\right)=\Sigma(\mathrm{Ni} / \mathrm{i})
$$

Where, $\mathrm{N}$ is the percentage of germinated seed in day $\mathrm{i}$.

$>$ Mean germination time (MGT): Lower MGT is the faster of germinated seeds. It was calculated by the following equation (Kader, 2005):

$$
\operatorname{MGT}(\mathrm{d})=\Sigma(\mathrm{NiTi}) /(\Sigma \mathrm{Ni})
$$

Where, $\mathrm{N}$ is the percentage of germinated seed in day $\mathrm{i}$, and $\mathrm{Ti}$ is the sequence of days from sowing.

> Root length, shoot length and root length/shoot length ratio: The length $(\mathrm{mm})$ and weight $\left(\mathrm{mg} \mathrm{plant}^{-1}\right)$ of seedling root and shoot were measured and recorded at the $12^{\text {th }}$ day after sowing (true leaf initiation stage). Root to shoot length ratio were estimated by dividing root length to shoot length.

\section{3 statistical Analysis}

Data was subjected to analysis of variance (ANOVA), using XLSTAT 2015.4.01.20780 software and the comparisons of trait' means for both factors and their interactions were made using Duncan's multiple range test at $5 \%$ level of probability. To interpret the relationships among studied criteria a biplot derived from principal component analysis (PCA) was conducted based on the rank correlation matrix of the two-way data from both selection criteria (germination and seedling traits) and genotypes. The analysis compared and grouped the wheat cultivars based on the studied characteristics. Cluster analysis based on squared Euclidean distance was also performed to classify the genotypes using the same software.

\section{Results and Discussion}

The yield of wheat as like as many other crops has been reduced significantly with the effect of drought. Detecting the genotypes those can thrive on limited water resource is critical to promote the wheat production under rain-fed condition (Ahmad, Shabbir, Minhas, \& Shah, 2013). Better use of water through the development of crop varieties with less water requirement and more drought tolerant is promising to satisfy the food demand for steadily increasing of the world population (El-Shafey, Hassaneen, Gabr, \& El-Sheihy, 2009; Xinqing, Kun, Shi-Kui, Xiao-Xia, \& Mu-Yi, 2006). Selection of tolerated wheat genotypes to water scarcity will help the breeding program in early tagging of drought tolerant genotype under stressed regions. Survival ability was investigated for seven common wheat cultivars in Kurdistan for the first time to tolerate chemical dehydration by PEG during the germination and early growth stage. The analysis results indicated significant variance of cultivars and PEG concentrations for most of the traits studied. However, their interactions declared a significant variance in shoot length trait only (Table 2). Significant effect and differential response of wheat varieties at seedling stage to PEG treatment were reported by some other researchers (Bayoumi, Eid, \& Metwali, 2008; Dhanda, Sethi, \& Behl, 2004). 
Table 2. Analysis of variance for the studied traits of seven wheat cultivars during in vitro drought stress, induced by four concentrations ( 0 to -15 bars) of polyethylene glycol 6000

\begin{tabular}{|c|c|c|c|c|c|c|c|c|c|c|c|c|}
\hline \multirow[b]{2}{*}{ Sources of variance } & \multirow[b]{2}{*}{ d.f. $^{a}$} & \multicolumn{11}{|c|}{ Mean square } \\
\hline & & $\begin{array}{l}\text { Germination } \\
(\%)\end{array}$ & $\begin{array}{l}\mathrm{MDG}^{b} \\
\text { (d) }\end{array}$ & $\begin{array}{l}\mathrm{CVG}^{c} \\
\left(\% \cdot \mathrm{d}^{-1}\right)\end{array}$ & $\begin{array}{l}\mathrm{GRI}^{d} \\
\left(\% \cdot \mathrm{d}^{-1}\right)\end{array}$ & $\begin{array}{l}\mathrm{MGT}^{e} \\
\text { (d) }\end{array}$ & $\begin{array}{l}\mathrm{RL} \\
(\mathrm{cm})\end{array}$ & $\begin{array}{l}\text { SHL } \\
(\mathrm{cm})\end{array}$ & $\begin{array}{l}\text { RW } \\
\left(\mathrm{mg} \cdot \text { plant }^{-1}\right)\end{array}$ & $\begin{array}{l}\text { SHW } \\
\left(\mathrm{mg} \cdot \text { plant }^{-1}\right)\end{array}$ & $\mathrm{RL} / \mathrm{SHL}^{f}$ & $\mathrm{RW} / \mathrm{SHW}^{g}$ \\
\hline Cultivars & 6 & $3874.44^{* *}$ & $24.10^{* *}$ & $4.97^{* *}$ & $710.63^{* *}$ & $3.70^{* *}$ & $189.12^{* *}$ & $106.04^{* *}$ & $181.29^{* *}$ & 113.157 & $1.15^{* *}$ & $0.613^{*}$ \\
\hline PEG conc. & 3 & $5065.33^{* *}$ & $17.05^{* *}$ & 0.66 & $206.01^{* *}$ & 0.36 & $37.37^{* *}$ & $282.72^{* *}$ & 74.37 & 86.541 & $0.66^{* *}$ & $0.822^{*}$ \\
\hline Cultivars $\times$ PEG conc. & 18 & $462.15^{* *}$ & 1.00 & 0.28 & 22.77 & 0.22 & 9.43 & $7.20 * *$ & 27.73 & 73.167 & 0.11 & 0.176 \\
\hline Residual & 56 & 177.95 & 0.80 & 0.31 & 19.17 & 0.23 & 7.70 & 3.08 & 29.30 & 56.695 & 0.08 & 0.101 \\
\hline Minimum & & 10.00 & 0.417 & 8.333 & 0.833 & 8.000 & 4.200 & 2.140 & 0.400 & 4.600 & 0.341 & 0.027 \\
\hline Maximum & & 100.00 & 8.333 & 12.500 & 40.417 & 12.000 & 25.200 & 20.560 & 46.000 & 56.000 & 2.079 & 2.609 \\
\hline Mean & & 67.67 & 3.244 & 11.748 & 14.680 & 8.559 & 9.571 & 11.058 & 17.056 & 16.827 & 0.957 & 1.116 \\
\hline Standard deviation & & 25.99 & 1.765 & 0.809 & 8.757 & 0.693 & 4.719 & 4.639 & 6.448 & 8.089 & 0.432 & 0.425 \\
\hline
\end{tabular}

Note. ${ }^{a}$ : Degree of freedom; ${ }^{b}$ : Mean Daily Germination; ${ }^{c}$ : Coefficient of Velocity of Germination; ${ }^{d}$ : Germination Rate Index; ${ }^{e}$ : Mean Germination Time; ${ }^{f}$ : Root length/shoot length ratio; ${ }^{g}$ : Root weight/shoot weight ratio.

${ }^{*},{ }^{* *}$ : Significant at $5 \%$ and $1 \%$ probability level, respectively.

\subsection{Germination Percentage (\%)}

Drought stress leads to drop the germination percent, due to less availability of free water to the kernel, as the PEG lowers the osmotic potential of the external medium (Datta, Mondal, Banerjee, \& Mondal, 2011). The germination percentages of all the seven cultivars were at the highest level for control treatment and started to decrease by increasing the level of water stress using PEG. These findings are in line with the result of Moayedi, Boyce, Barakba, and Ghodsi (2009) who reported that the decline in germination percentage was observed with increasing the osmotic stress up to $-0.9 \mathrm{Mpa}$.

It can be concluded that reducing in germination percentage is associated with either decreasing the water absorption into the seeds or delaying of the germination events (Khan et al., 2013). The decreasing trend in germination was generally the same for all three germination periods, counting for most of the cultivars except the germination after four days for Azadi cultivar (Figure 1). At this stage, the germination was linearly increased with the increased water stress. Short exposing of the kernel (only four days) to the induced condition had less stress effect on the germination process, which might be a reason of the lineared increased germination. While at the eighth and twelves days the germination of this cultivar was more affected by the induced stress due to longer exposing to the induced water stress. Azadi had less germination ration compared to control, but with a little effect compared to other cultivars, as it showed better performance to resist the stressed condition.

Regardless of the water stress, Azadi cultivar had the highest percentage of germination at $12^{\text {th }}$ day. The last stress condition (at -15 bars of osmotic pressure) exhibited better germination performance (98\%) for Azadi compared to other cultivars. It has been indicated that when a grain accomplishes a critical level of hydration it will be proceed toward a full germination without stopping (Almaghrabi, 2012). This cultivar considered being drought tolerant as their germination percentage did not reduce significantly with the increased moisture stress during germination, because some plants can develop their biochemical and physiological function to tolerate the water deficient condition (Chachar et al., 2016). However, the physiological changes below the critical level of hydration could be effective and inhibit the germination, attaining a critical level of hydration for this genotype (40\%) made the germination to be proceed without cessation (Chachar et al., 2014). Adana cultivars at the second osmotic solution ( -5 bar) had higher germination percent compared to control condition after Azadi; then it was linearly reduced to less germination percent compared to control treatment. Among all the cultivars Rizgari was the most affected by water stress, giving the lowest and significant germination percent (Table 3 ). 


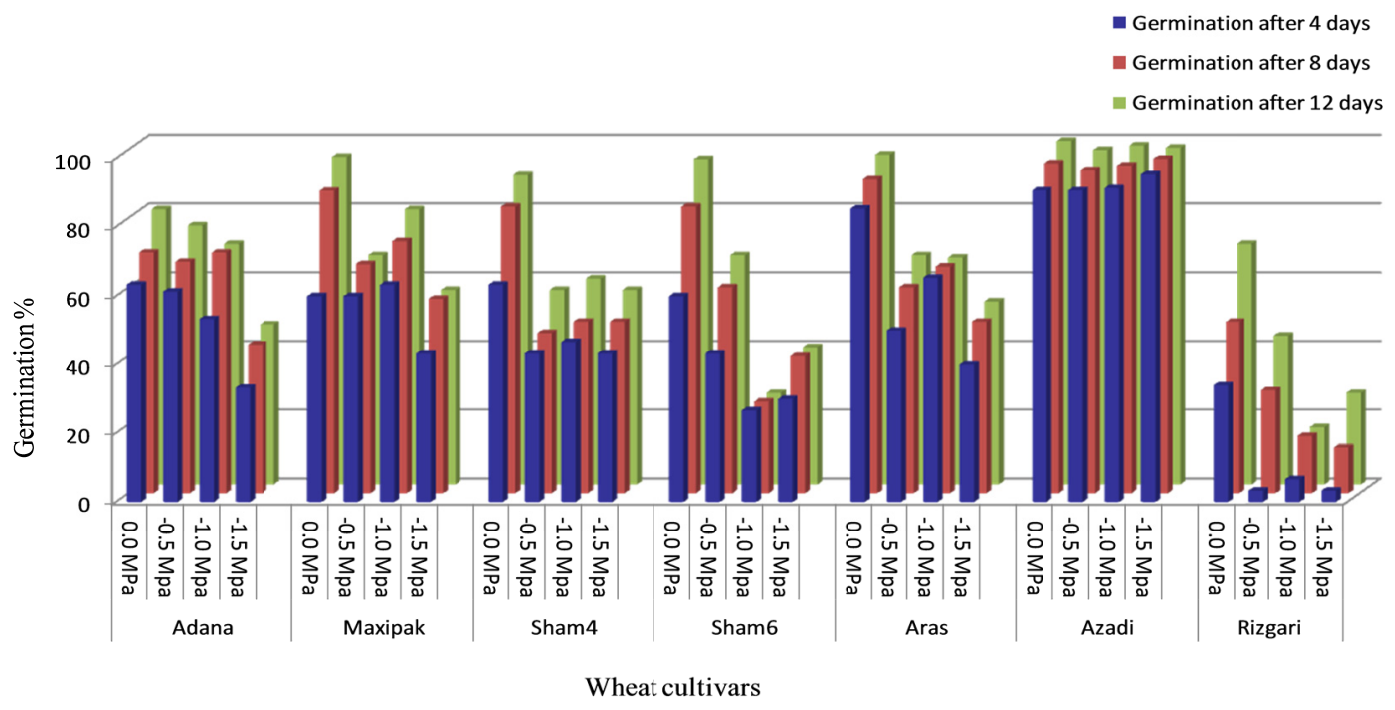

Figure 1. Effect of different levels of osmotic stress induced by PEG 6000 (-MPa) on the germination of seven wheat cultivars at three different times (after 4,8 and 12 days)

Different respond of the cultivars to drought stress could be resulted from the amount of water absorbed, size of the seeds, and the features of surface coating of the seeds (Mohammadi \& Mojaddam, 2014). This certain criteria is important and can be used in selecting drought-resistant cultivars (Qayyum, Razzaq, Ahmad, \& Jenks, 2011). Although, some other researchers (Baloch et al., 2012; Sayar, Khemira, Kameli, \& Mosbahi, 2008) stated non-significant discrimination among some wheat genotypes for germination. The high variation of the current cultivars responded to different osmotic stresses indicates a wide range of genetic variation among them, being suitable genetic materials in developing new genotypes for the arid condition, as the tolerant genotypes could be screened and tagged at seedling stage before extensive and expensive field trial (Baloch et al., 2012).

Table 3. Effect of cultivars and different drought stress conditions induced by PEG 6000 on the studied characters of seven wheat cultivars

\begin{tabular}{|c|c|c|c|c|c|c|c|c|c|c|c|c|}
\hline \multicolumn{2}{|c|}{ Factor } & $\begin{array}{l}\text { Germination } \\
(\%)\end{array}$ & $\begin{array}{l}\mathrm{MDG}^{a} \\
\text { (d) }\end{array}$ & $\begin{array}{l}\mathrm{CVG}^{b} \\
\left(\% \cdot \mathrm{d}^{-1}\right)\end{array}$ & $\begin{array}{l}\mathrm{GRI}^{c} \\
\left(\% \cdot \mathrm{d}^{-1}\right)\end{array}$ & $\begin{array}{l}\mathrm{MGT}^{d} \\
\text { (d) }\end{array}$ & $\begin{array}{l}\mathrm{RL} \\
(\mathrm{cm})\end{array}$ & $\begin{array}{l}\text { SHL } \\
(\mathrm{cm})\end{array}$ & $\begin{array}{l}\text { RW } \\
\left(\mathrm{mg} \cdot \text { plant }^{-1}\right)\end{array}$ & $\begin{array}{l}\text { SHW } \\
\left(\mathrm{mg} \cdot \text { plant }^{-1}\right)\end{array}$ & $\mathrm{RL} / \mathrm{SHL}^{e}$ & $\mathrm{RW} / \mathrm{SHW}^{f}$ \\
\hline \multirow{7}{*}{$\stackrel{\stackrel{\mathscr{E}}{\Xi}}{\stackrel{\Xi}{\Xi}}$} & Adana & $68.000 \mathrm{bc}$ & $2.917 \mathrm{bc}$ & $12.001 \mathrm{a}$ & $13.854 b c$ & $8.337 b$ & $6.564 \mathrm{c}$ & $8.909 \mathrm{de}$ & $13.233 \mathrm{c}$ & $13.083 b$ & $0.809 \mathrm{~cd}$ & $1.065 \mathrm{~b}$ \\
\hline & Maxipak & $74.667 \mathrm{~b}$ & $3.299 \mathrm{~b}$ & $11.916 \mathrm{a}$ & $14.913 b$ & $8.402 b$ & $6.151 \mathrm{c}$ & $9.50 \mathrm{cde}$ & $13.842 b c$ & $13.700 \mathrm{~b}$ & $0.778 \mathrm{~cd}$ & $1.064 \mathrm{~b}$ \\
\hline & Sham4 & $65.833 \mathrm{bc}$ & $2.847 \mathrm{bc}$ & $11.886 \mathrm{a}$ & $12.691 \mathrm{bc}$ & $8.422 b$ & $6.769 \mathrm{c}$ & $8.057 \mathrm{e}$ & $14.931 \mathrm{bc}$ & $17.268 \mathrm{ab}$ & $1.140 \mathrm{~b}$ & $0.980 \mathrm{~b}$ \\
\hline & Sham6 & $57.000 \mathrm{c}$ & $2.500 \mathrm{c}$ & $11.951 \mathrm{a}$ & $10.781 \mathrm{c}$ & $8.384 b$ & $6.364 \mathrm{c}$ & $10.719 \mathrm{c}$ & $18.563 b$ & $22.425 \mathrm{a}$ & $0.647 \mathrm{~d}$ & $0.971 b$ \\
\hline & Aras & $70.500 \mathrm{~b}$ & $3.333 b$ & $12.078 \mathrm{a}$ & $16.198 b$ & $8.292 b$ & $13.218 \mathrm{ab}$ & $13.524 b$ & $15.755 \mathrm{bc}$ & $16.333 \mathrm{ab}$ & $1.006 \mathrm{bc}$ & $1.000 \mathrm{~b}$ \\
\hline & Azadi & $98.500 \mathrm{a}$ & $6.181 \mathrm{a}$ & $12.106 \mathrm{a}$ & $29.826 a$ & $8.263 b$ & $12.600 \mathrm{~b}$ & $16.533 \mathrm{a}$ & $18.583 b$ & $17.233 \mathrm{ab}$ & $0.768 \mathrm{~cd}$ & $1.116 \mathrm{~b}$ \\
\hline & Rizgari & $39.167 \mathrm{~d}$ & $1.632 \mathrm{~d}$ & $10.300 \mathrm{~b}$ & $4.497 \mathrm{~d}$ & $9.810 \mathrm{a}$ & $15.334 \mathrm{a}$ & $10.168 \mathrm{~cd}$ & $24.468 \mathrm{a}$ & $17.746 \mathrm{ab}$ & $1.551 \mathrm{a}$ & $1.614 \mathrm{a}$ \\
\hline \multirow{4}{*}{$\begin{array}{l}\dot{0} \\
0 \\
0 \\
0 \\
\text { 핌 }\end{array}$} & $0.0 \mathrm{MPa}$ & $89.429 a$ & $4.563 \mathrm{a}$ & $11.586 \mathrm{~b}$ & $19.206 a$ & $8.649 a$ & $11.322 \mathrm{a}$ & $16.456 \mathrm{a}$ & $14.638 b$ & $18.771 \mathrm{a}$ & $0.694 \mathrm{~b}$ & $0.824 b$ \\
\hline & $-0.5 \mathrm{Mpa}$ & $67.524 b$ & $3.056 \mathrm{~b}$ & $11.744 \mathrm{ab}$ & $13.978 \mathrm{~b}$ & $8.565 \mathrm{a}$ & $9.656 \mathrm{ab}$ & $9.872 b$ & $16.531 \mathrm{ab}$ & $14.002 \mathrm{a}$ & $1.016 \mathrm{a}$ & $1.188 \mathrm{a}$ \\
\hline & $-1.0 \mathrm{Mpa}$ & $59.714 b$ & $2.778 b$ & $11.995 \mathrm{a}$ & $13.522 b$ & $8.371 \mathrm{a}$ & $9.194 b$ & $9.650 \mathrm{~b}$ & $18.238 \mathrm{a}$ & $17.596 a$ & $1.042 \mathrm{a}$ & $1.185 \mathrm{a}$ \\
\hline & $-1.5 \mathrm{Mpa}$ & $54.000 \mathrm{~b}$ & $2.579 \mathrm{~b}$ & $11.668 \mathrm{ab}$ & $12.014 b$ & $8.650 \mathrm{a}$ & $8.114 b$ & $8.255 \mathrm{c}$ & $18.818 \mathrm{a}$ & $16.938 \mathrm{a}$ & $1.077 \mathrm{a}$ & $1.265 \mathrm{a}$ \\
\hline
\end{tabular}

Note. ${ }^{a}$ : Mean Daily Germination; ${ }^{b}$ : Coefficient of Velocity of Germination; ${ }^{c}$ : Germination Rate Index; ${ }^{d}$ : Mean Germination Time; ${ }^{e}$ : Root length/shoot length ratio; ${ }^{f}$ : Root weight/shoot weight ratio.

\subsection{Mean Daily Germination}

The mean square results showed a significant effect of cultivars and polyethylene glycol on mean daily germination at $1 \%$ level. As like as germination percent the highest value of mean daily germination ( 6.181 days) was for Azadi cultivar (Table 3). Rizgari was the most affected cultivar with the drought stress (Figure 2) giving 
the minimum MDG value (1.632 days). The highest reduction percent of the induced stress compared to control (58.73\%) for MDG was referred to Rizgari confirming its sensitivity to drought stress during the germination period. Sham 6 also gave a closed ratio of MDG reduction for the stressed conditions compared to distilled water. The results here indicate decreasing in mean daily germination due to the reduction of osmotic pressure from 0.00 bar (control) to -15 bar. Decreasing of mean daily germination is resulted from requiring more time to germinate as the drought stress increased (Zare', Tavili, \& Shahbazi, 2010).

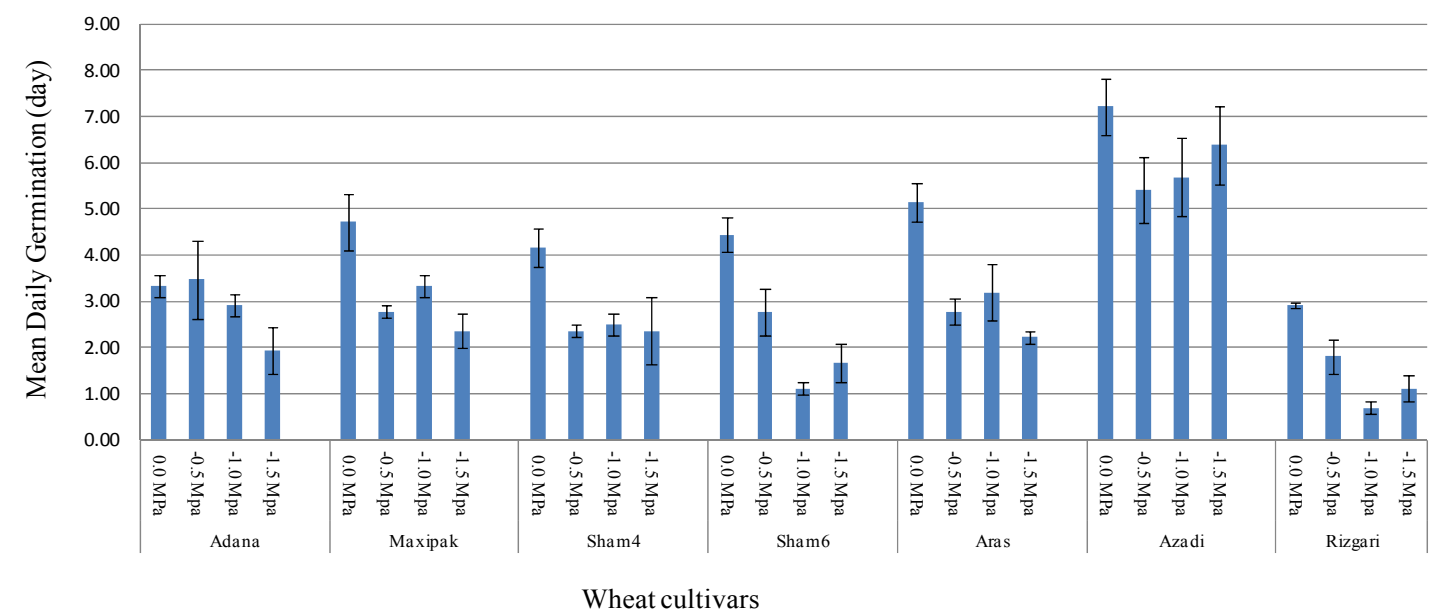

Figure 2. Effect of water stress on the Mean daily germination of seven wheat cultivars counted for 12 days

\subsection{Coefficient of Velocity of Germination (CVG)}

The mean square value of CVG was significantly different at $1 \%$ level among the various cultivars. While non-significant mean square was observed for different levels of drought stress and their interaction with the cultivars. The lowest coefficient of the velocity of germination was observed for control treatment and it was increased with the increased drought stress. This trend was realized in most of the cultivars (Figure 3). Azadi had the highest CVG value of 12.106, followed by Aras cultivar, as they were appeared to be more tolerant to drought stress conditions. Despite the necessity of high energy for biological processes under the stress condition, the cultivars under study were able to continue in their physiological activities to give higher CVG value compared to control treatment. Similar results were obtained for some wheat cultivars induced to water stress by Almaghrabi (2012) using Polyethylene Glycol at different concentration levels. Based on the result obtained for $\mathrm{CVG}$, Azadi performed higher adaptation to drought stress condition compared to other cultivars.

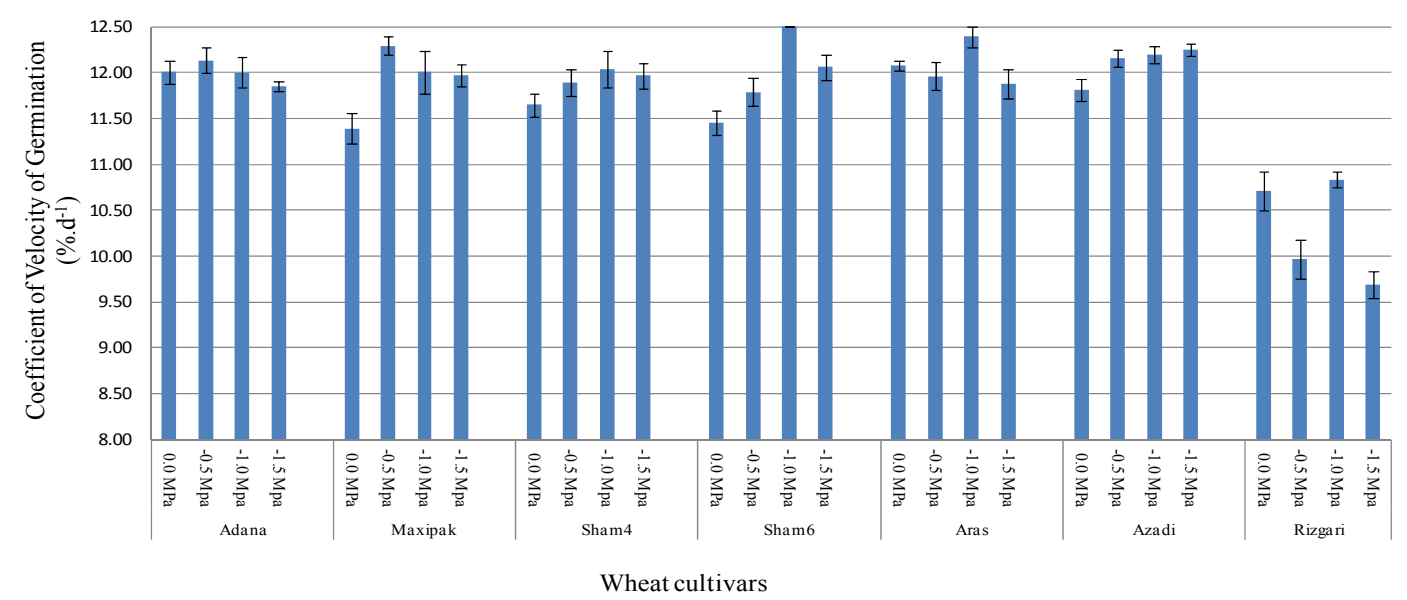

Figure 3. Effect of water stress on the coefficient of velocity of germination of seven wheat cultivars 


\subsection{Germination Rate Index (GRI)}

It has been reported by Gholamin and Khayatnezhad (2010) that water stress in wheat starts with dropping the rate of germination and seedling growth. As like as germination the mean squares of cultivars and PEG concentrations of GRI were highly significant $(1 \%)$, while the mean square values of their interaction were not significant (Table 2). The highest value of germination rate index was observed for Azadi cultivars (29.826), indicating the high tolerance of the cultivar to water stress (Figure 4). While the lowest value was recorded for Rizgari, being the most sensitive to give the maximum reduction of GRI (66.40\%) compared to control. This fact is in accordance with what was obtained by Mollasadeghi, Ghanifathi, Masoumzadeh, \& Aghahasanbeyglo (2014) who reported the high susceptibility of germination rate index in some bread wheat cultivars to the variation in osmotic potential.

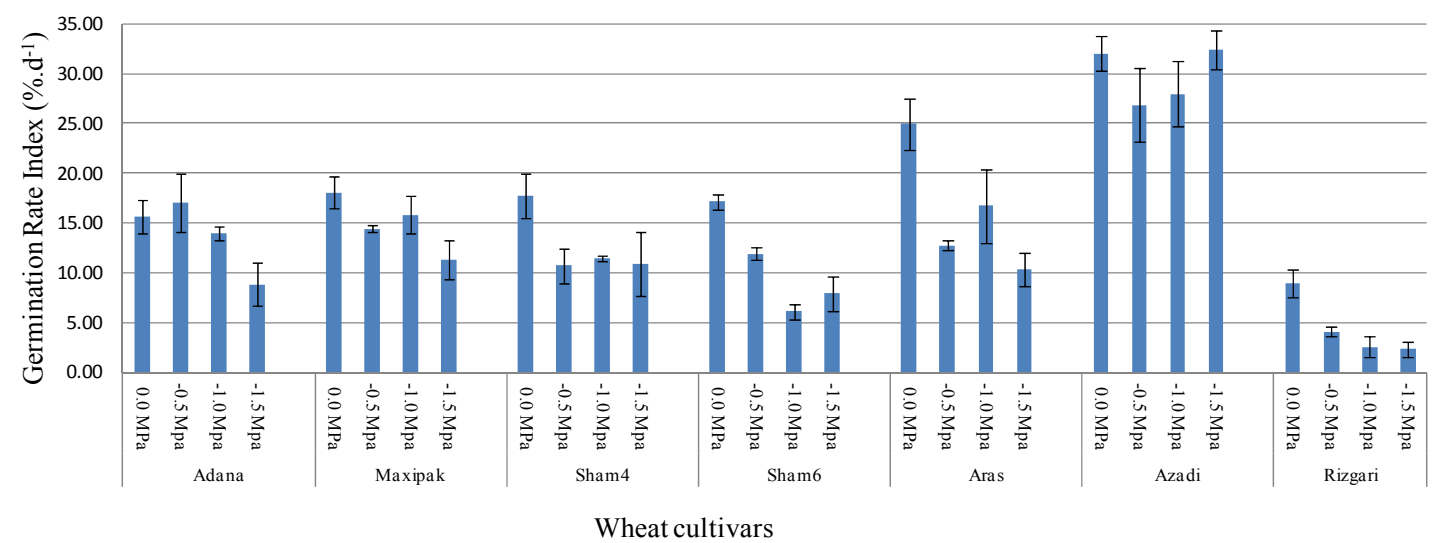

Figure 4. Effect of water stress on the germination rate index of seven wheat cultivars

\subsection{Mean Germination Time (MGT)}

It is clear from data presented in Table 2 that MGT was significantly affected by different wheat cultivars while no significant differences were observed in term of Polyethylene concentration and their interaction with cultivars. Significant differences was also obtained among different wheat genotypes for MGT at different levels of PEG 6000 and putrescine (Aydin, Pour, Haliloğlu, \& Tosun, 2015). The minimum value of mean germination time (8.26 days) was found for Azadi, showing higher tolerant to the increased concentration of PEG when compared to other cultivars. Increased PEG concentration had a negative and significant impact on mean germination time for Rizgari cultivar (Figure 5), giving higher and significant value of 9.810 days. Less water availability under high concentration of PEG 8000 is one of the reasons to increase mean germination time (Iqbal \& Ashraf, 2006).

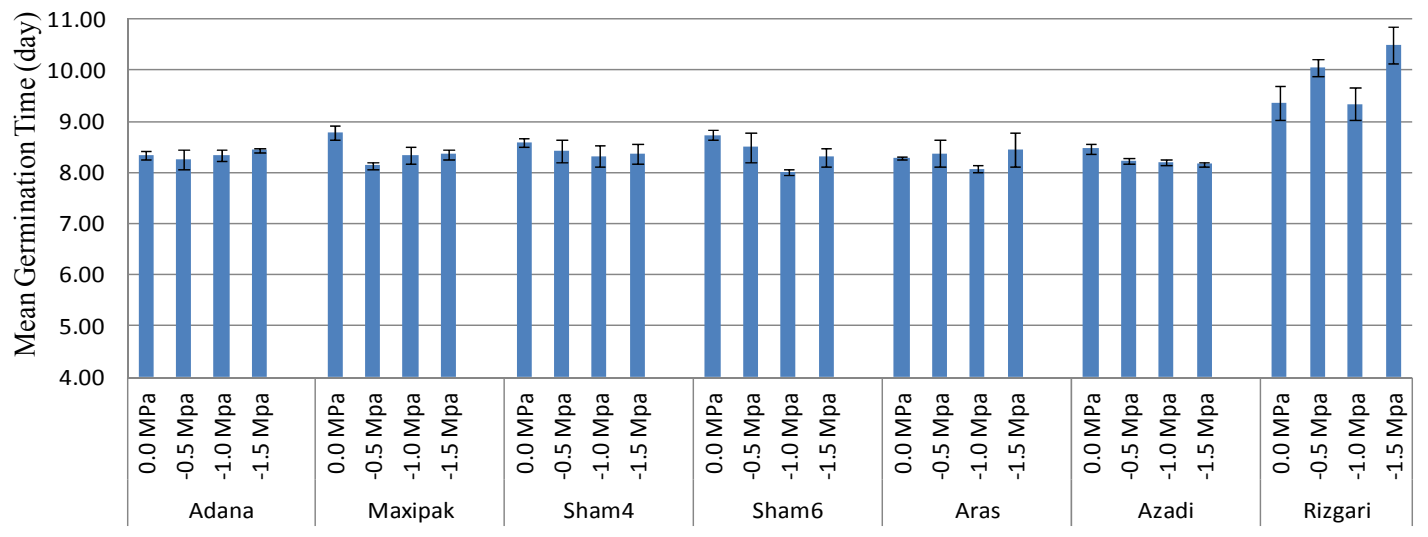

Wheat cultivars

Figure 5. Effect of water stress on the mean germination time of seven wheat cultivars 


\subsection{Root Length (cm)}

Root length in wheat crop considered as the most powerful trait among the seedling growth parameters in drought tolerance selection program (Baloch et al., 2012; Hassan, Mohamed, El-Rawy, \& Amein, 2016). The increased concentrations of PEG at seedling growth stage had influenced the root length of wheat seedling. Rizgari cultivars had recorded the maximum root length of $15.33 \mathrm{~cm}$ (Table 3) compared to the others, showing the ability to perform root formation at the drought stress. Measuring such growth parameters to drought at the seedling stage may alleviate consequent depression and indicate the existence of potential variability resources of the genotypes to drought resistance (Biesaga-Kościelniak et al., 2014). However Azadi cultivar had less root length compared to Rizgari and Aras, the increase in root length had indicated by $28 \%$ compared to control when induced to the different PEG concentrations (Figure 6). It has been indicated that the root architecture has an influence on the agronomic trait and the yield of crop. A deeper and more extended root system allow the seedlings to extract more water in surrounded soil (de Dorlodot et al., 2007).

The development of root system in Azadi cultivar under drought stress could be explained by the stimulation of certain gene (s) of root formation (Placido et al., 2013). The shortest root due to the PEG treatment was recorded for Maxipak cultivar. Decrease in the root length might be resulted from the diminish relative turgidity and protoplasm dehydration, that brings down cell expansion and delaying the cell division (Mujtaba, Summiya, Khan, Mumtaz, \& Barakat, 2016).

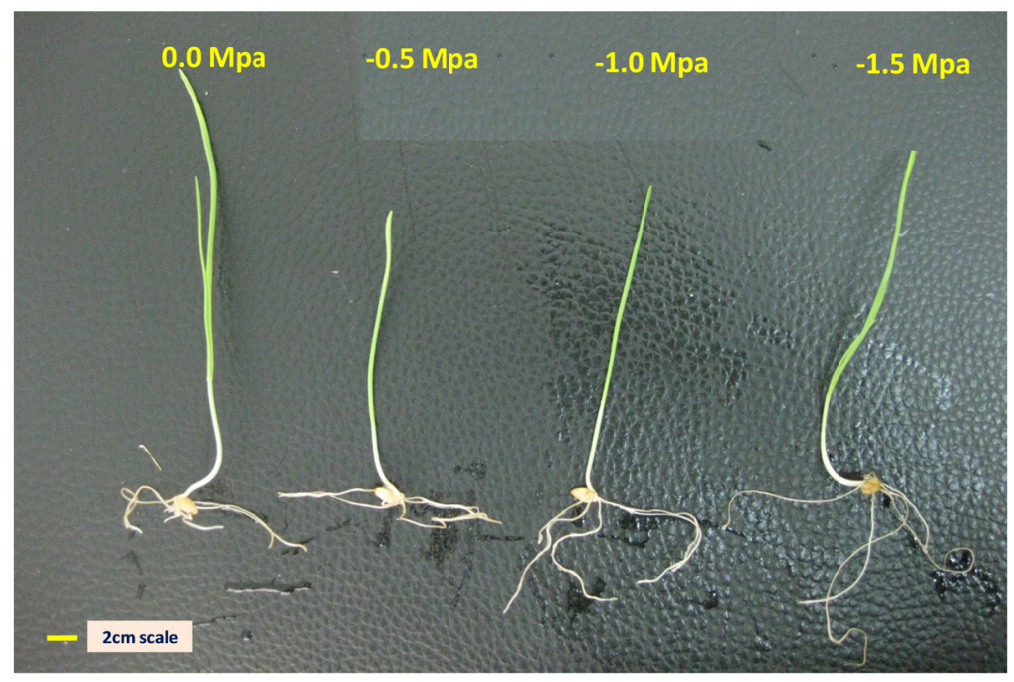

Figure 6. Rooting performance for Azadi cultivar under different stress levels $(0.0 \mathrm{Mpa},-0.5 \mathrm{Mpa},-1.0 \mathrm{Mpa}$ and $-1.5 \mathrm{Mpa})$

\subsection{Shoot Length (cm)}

Presence of the increased PEG 6000 concentrations during the seedling growth had certainly reduced the shoot development and wheat seedling survival. The drought resistance is qualified by a small reduction of shoot growth under drought stressed condition (Moucheshi, Heidari, \& Assad, 2012). The cultivars were differed in the length of seedling shoot under different levels of water stress. Maximum shoot length of $16.5 \mathrm{~cm}$ was recorded for Azadi cultivar (Table 3), giving less reduction percent of the induced stresses (23\%) compared to the control treatment. While the lowest length was observed for Sham4 (Figure 7), recording the maximum reduction of $65.6 \%$ when compared to the control. A significant decrease in root and shoot length of wheat under water stress has been realized by other researchers (Gholamin \& Khayatnezhad, 2010). Longer coleoptiles under water stress are one of the advantages of allowing the seedling emergence and establishment (Chachar et al., 2014). 


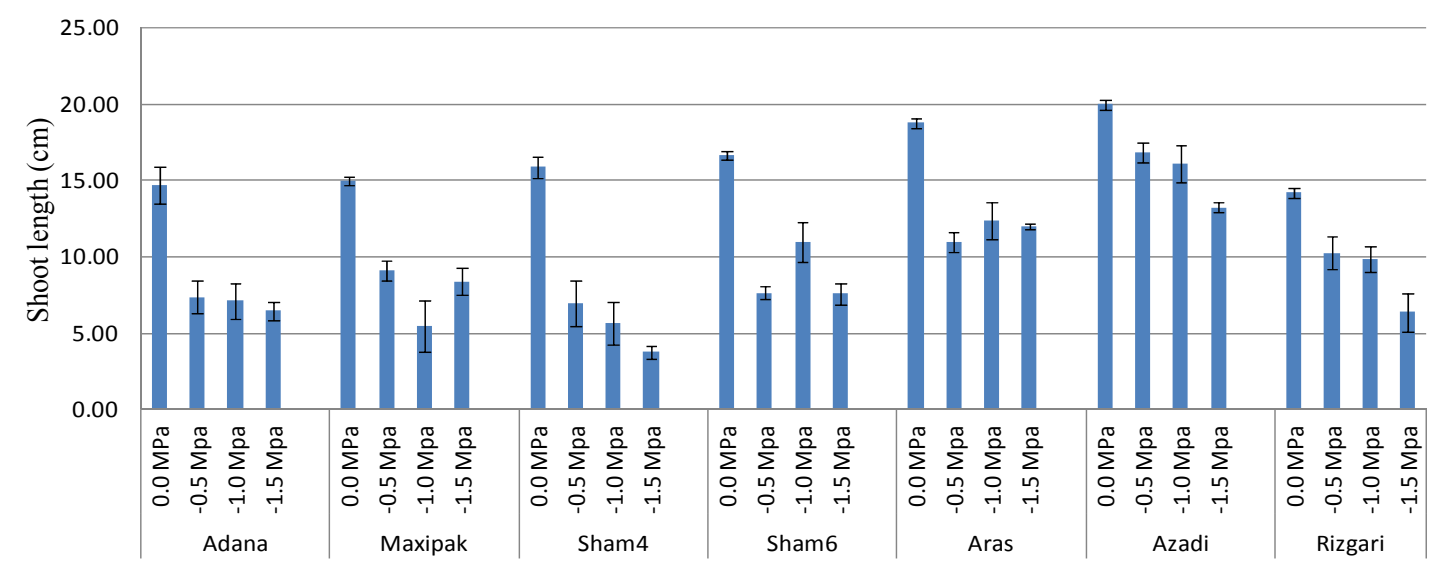

Wheat cultivars

Figure 7. Effect of water stress on the shoot length of seven wheat cultivars

Apart from the root and shoot lengths, root/shoot ratio also being a good indicator to tag the drought tolerant genotype. The present study revealed significant variations for the root/shoot ratio between the cultivars (Figure 8). It has been indicated that drought resistant genotypes had balanced root and shoot growth (Dhanda, Sethi, \& Behl, 2004). Less differences in root/shoot ratio for different drought stresses was for Rizgari to give $13.4 \%$, followed by Aras and Azadi. For some of the cultivars, the increased value of root/shoot ratio was observed with the increase in PEG concentration. Physiological activities of the root system are realized to be less sensitive to low water content, while sap transferring to the upper part of seedling required higher water potential (Sani \& Boureima, 2015).

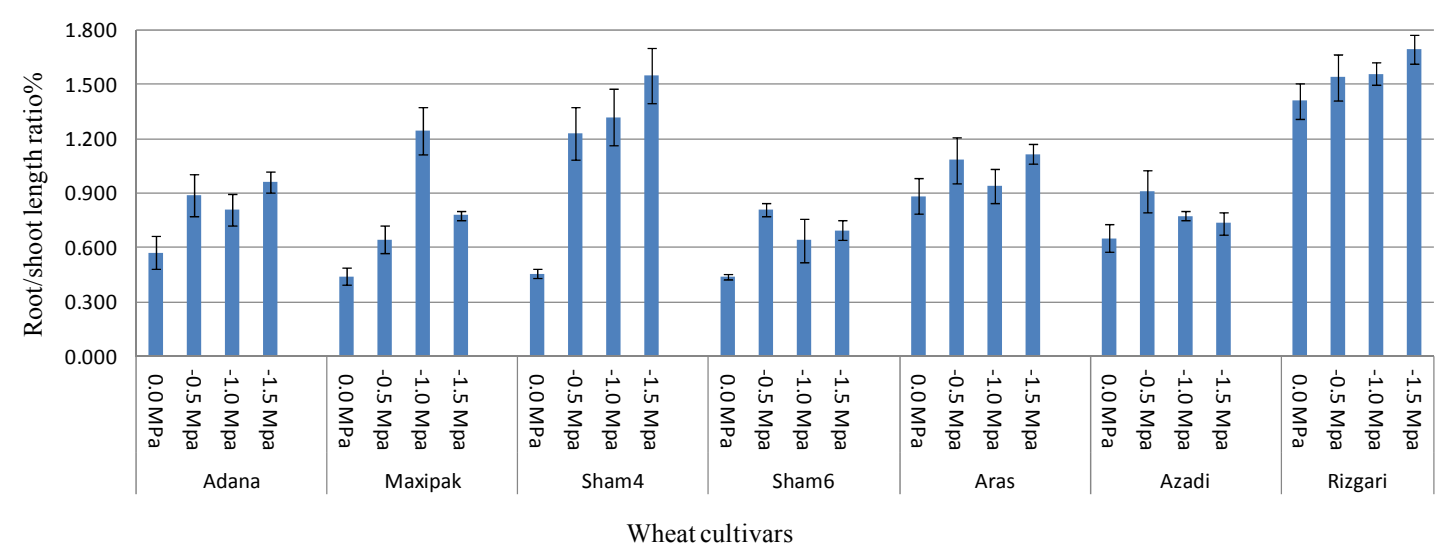

Figure 8. Effect of water stress on the coefficient of root/shoot length ratio of seven wheat cultivars

\subsection{Root and Shoot Dry Weight ( $\mathrm{mg} /$ seedling)}

Racing the concentration of PEG had recorded the progressive increasing in root weight at different rates for all cultivars except Aras (Figure 9). Under high PEG treatment (-10 and -15 bar), the maximum root weight was recorded for Rizgari and Sham6 cultivars. 


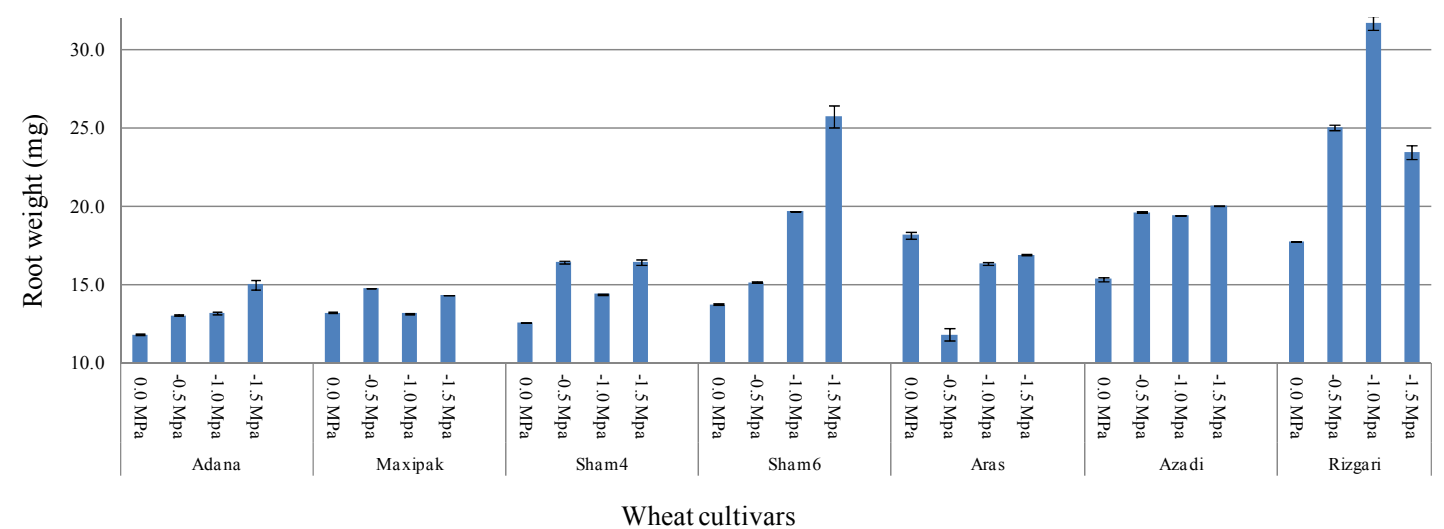

Figure 9. Effect of water stress on the seedling root weight of seven wheat cultivars

PEG prompted a decrease in shoot weight in number of cultivars (Figure 10). The reduction in shoot fresh weight was attributed to less number and smaller leave development with the increased PEG concentration of the growth media. The minimum shoot weight was observed for Adana while the maximum shoot weight was recorded for Sham6, followed by Rizgari (Table 3).

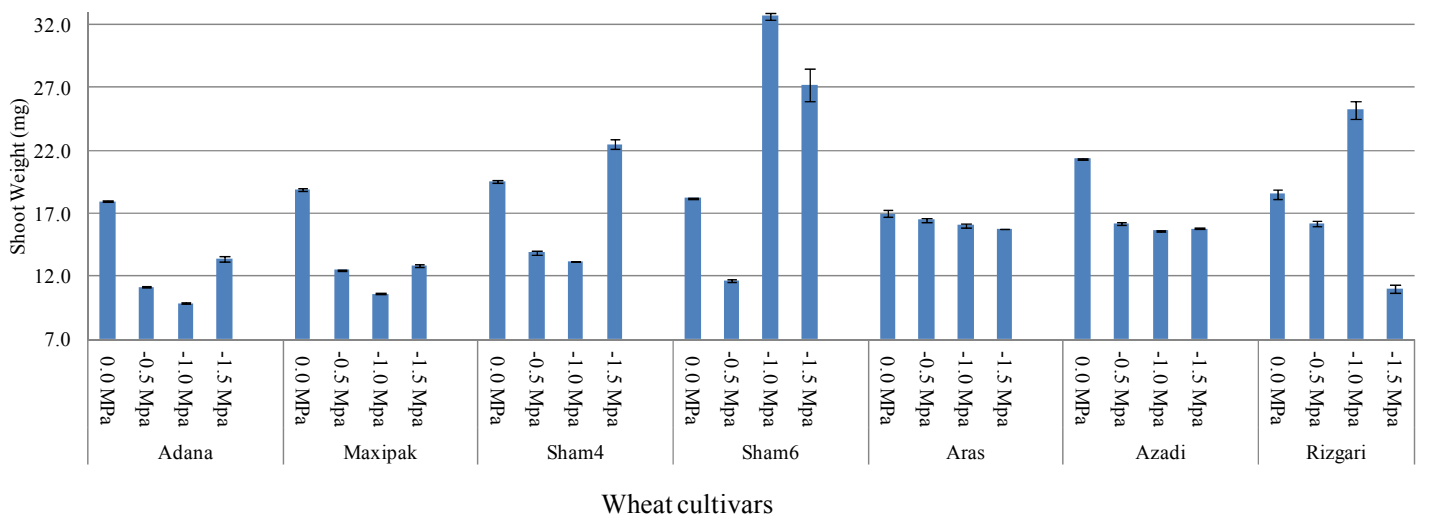

Figure 10. Effect of water stress on the seedling shoot weight of seven wheat cultivars

It is important that drought resistance is categorized by a small reduction of shoot growth under drought stressed condition (Ming, Pei, Naeem, Gong, \& Zhou, 2012; Moucheshi, Heidari, \& Assad, 2012). However the high root/shoot weight ratio was observed for Rizgari cultivar, the most persistent cultivar was Azadi, being more stable in the ratio of root/shoot weight (23.12\%) for different stress conditions compared to control treatment.

\subsection{Principal Component Analysis (PCA)}

The PCA analysis was performed, as the most frequently used multivariate method, to assess the relationships between all attributes to identify superior cultivar (s) for the water-stressed condition. The relationships among different parameters were graphically displayed in a biplot of PCA1 and PCA2, based on the rank correlation matrix. Biplot diagram revealed that the first and second components justified $54.77 \%$ and $28.83 \%$ of total variation, respectively, with different characteristics studied (Table 4) and accounted for $83.60 \%$ of total variation. 
Table 4. Principal component analysis for the studied traits of seven wheat cultivars

\begin{tabular}{lll}
\hline Traits & F1 & F2 \\
\hline Germination & 0.308 & 0.348 \\
MDG & 0.308 & 0.348 \\
CVG & 0.393 & -0.112 \\
GRI & 0.332 & 0.310 \\
MGT & -0.392 & 0.122 \\
RL & -0.181 & 0.459 \\
SHL & 0.161 & 0.492 \\
RWT & -0.295 & 0.328 \\
SHWT & -0.079 & 0.092 \\
RL/SHL & -0.349 & 0.106 \\
RWT/SHWT & -0.344 & 0.234 \\
Eigenvalue & 6.025 & 3.172 \\
Variability $(\%)$ & 54.771 & 28.833 \\
Cumulative \% & 54.771 & 83.605 \\
\hline
\end{tabular}

Three groups were identified considering both components simultaneously (Figure 11). The germination, MDG, GRI and SHL were clustered in group I, while MGT, RL, RWT, SHWT, RL/SHL, RWT/SHWT were associated with group II and CVG with group III.

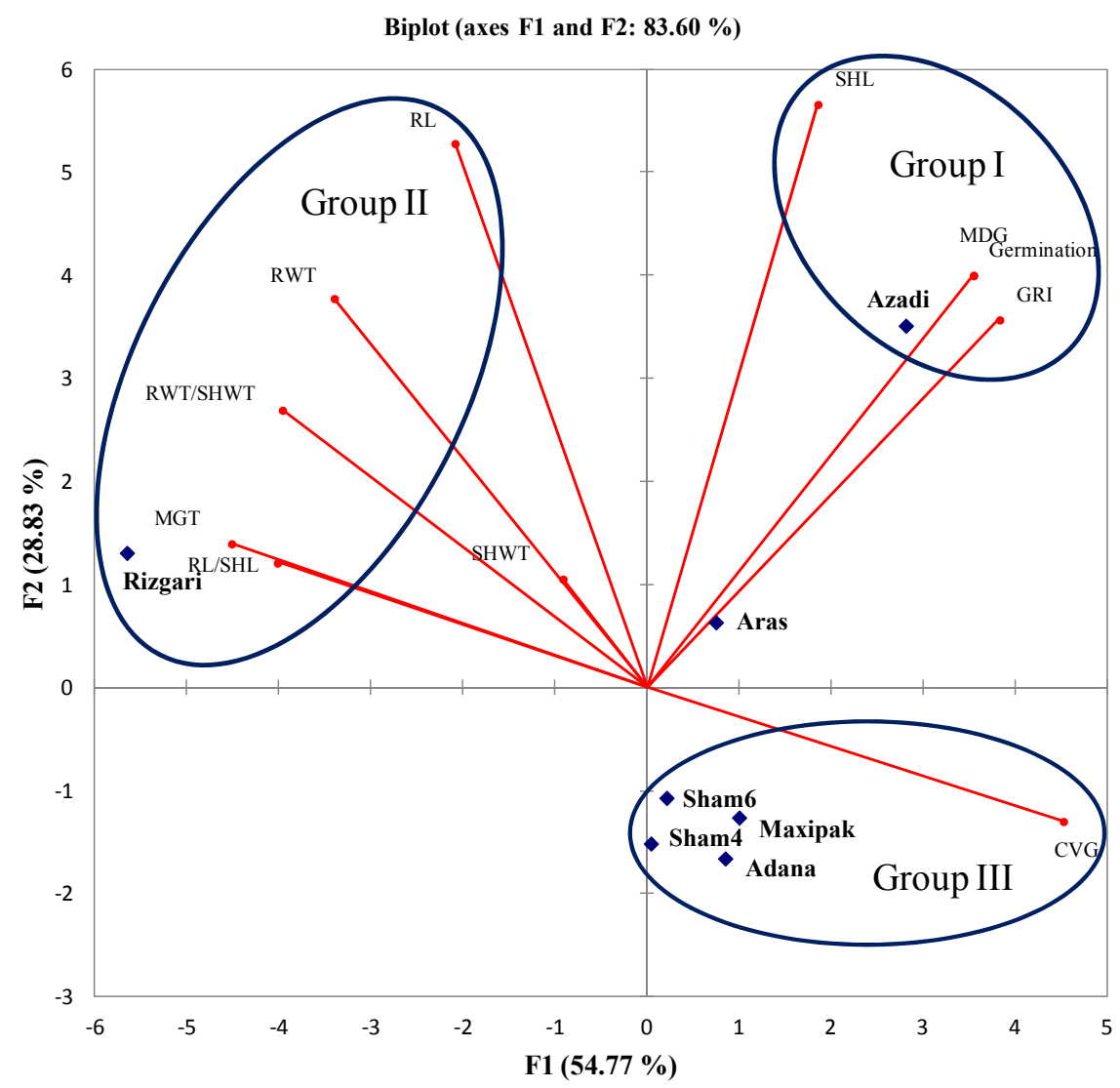

Figure 11. Biplot of principal component analysis of seven wheat cultivars and studied traits. Group I - high water stress resistant cultivars during germination process; Group II - high water stress tolerant for seedling characteristics; Group III - low water stressed cultivars for germination and seedling characteristics 
Group I consists of Azadi cultivar, which has a good performance for germination, MDG, GRI and SHL under induced water stress (Figure 11). The cosine of the angle between the vectors of two characteristics approximates the correlation between them. Shoot length found to be in a positive and significant association with germination and MDG and GRI, meaning that prediction of the Shoot length as one of the drought-resistant trait could be explained through germination. Ahmad, Shabbir, Minhas, and Shah (2013) had similar result in identifying a strong positve correlation between Shoot lenght and germination pecent. In the second group (II), Rizgari was superior in MGT and most of the seedling traits, explaining its resistance in seedling traits under induced water stress and all of these traits were in a strong and negative association with CVG. Group III included most of the cultivars studied having a good germination velocity, showing negative and significant association with most of the traits of second group. The cultivars here were variable in their resistance to water-stressed conditions according to the traits studied. Biplot analysis has been used widely by other researchers for screening drought tolerant cultivars of wheat (El-Mohsen, El-Shafi, Gheith, \& Suleiman, 2015; Farshadfar, Elyasi, \& Aghaee, 2012). However the variation angles of the dataset with Biplot analysis does not precisely translated into correlation coefficients, the angles are informative enough to reflects the importance of the largest contributor to the total variation at each axis of differentiation (Abdi \& Williams, 2010).

\subsection{Cluster Analysis}

As like as PCA, the cluster analysis classified the cultivars for the induced drought, based on the traits studied, into three groups of 1, 1 and 5 cultivars, respectively (Figure 12). The first group contained Azadi with higher germination rate and shoot length, and it was considered as a drought resistant group especially at germination stage. The second group consisted of Rizgari with higher performance for the seedling characteristics when exposed to the drought condition using PEG-6000. While the rest of cultivars were grouped in the third cluster showing their reasonable performance for CVG only with the variable response for other traits studied during the water stress conditions. Biplot results of the current study are in agreement with cluster analysis in identifying the same tolerant genotypes for the induced water stress. Cluster analysis has been utilized to describe the variation and grouping the genotypes based on drought tolerance indices (El-Mohsen, El-Shafi, Gheith, \& Suleiman, 2015; Golabadi, Arzani, \& Maibody, 2006).

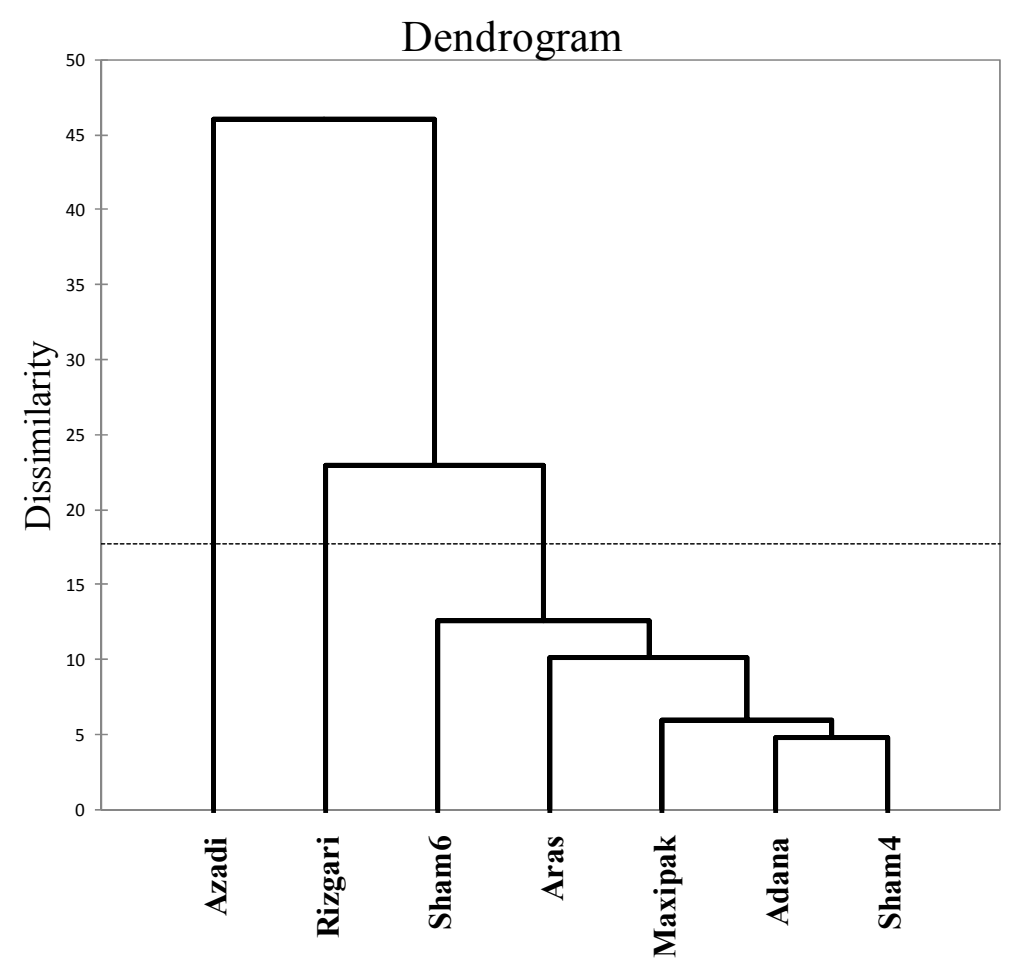

Figure 12. Dendrogram of seven wheat cultivars based on cluster analysis using various germination and seedling characteristics. Group I including Azadi cultivar (drought tolerant during germination), Group II including Rizgari cultivar (drought tolerant at seedling stage) and, Group III including five cultivars of Sham6, Aras, Maxipak, Adana and Sham4 (variable drought resistant) 


\section{Conclusion}

In the current study osmotic stress caused significant effects on the germination and seedling traits of the studied cultivars. Azadi cultivar had the best performance for most of the traits under the drought stress conditions, which indicates the contributor characteristics of this genotype in tolerating drought stress. The introgression of desired allele (s) of stress tolerance from the related wild species into Azadi cultivar under local condition could be the reason of superiority of this cultivar under water stress. Rizgari cultivar had better performance for the seedling characteristics more than germination progress. It shows higher root length and root weight than other cultivars under induced water stress. Hence, Rizgari could tolerate drought stress at the seedling and later stages if passed the germination period at regular water status. This cultivar suits the local condition as most of the drought stress will come after the germination period. The best response of these two cultivars to drought stress condition could assure their suitability to be cultivated in arid and semiarid areas of Kurdistan.

Principle component analysis and Cluster analysis were in support to the analysis of variance to discriminate the genotypes at different level of drought stress through the studied characteristics. All three analysis positioned the genotype into three distinct groups; Azadi was tolerant to water stress throughout most of the germination characteristics, making the first group. Rizgar as the second group was suitable to resist the water stress during the seedling growth. While other cultivars had variable level of resistance to the induces stress for the studied characteristics.

The parameters here are found to be a useful index to discriminate drought tolerant genotypes at early growing stage under induced water-stressed environments. The current study will help the breeder for rapid selection of the tolerant genotype for any breeding program, avoiding extensive field trials.

\section{References}

Abdi, H., \& Williams, L. J. (2010). Principal component analysis. Wiley Interdisciplinary Reviews: Computational Statistics, 2(4), 433-459. https://doi.org/10.1002/wics.101

Ahmad, M., Shabbir, G., Minhas, N., \& Shah, M. (2013). Identification of drought tolerant wheat genotypes based on seedling traits. Sarhad J. Agric., 29(1), 21-27. Retrieved from https://www.researchgate.net/ publication/263002286

Al-Ghamdi, A. A. (2009). Evaluation of oxidative stress tolerance in two wheat (Triticum aestivum) cultivars in response to drought. International Journal of Agriculture and Biology, 11(1), 7-12. Retrieved from https://www.fspublishers.org/published_papers/76090_..pdf

Almaghrabi, O. A. (2012). Impact of drought stress on germination and seedling growth parameters of some wheat cultivars. Life Science Journal, 9(1), 590-598. Retrieved from http://www.lifesciencesite.com/ 1sj/life0901/087_8160life0901_590_598.pdf

Aydin, M., Pour, A. H., Hali̇loğlu, K., \& Tosun, M. (2015). Effect of Putrescine Application and Drought Stress on Germination of Wheat (Triticum aestivum L.). Journal of the Faculty of Agriculture, 46(1), 43-55. Retrieved from http://e-dergi.atauni.edu.tr/ataunizfd/article/download/5000186286/5000163975.

Baloch, M. J., Dunwell, J., Khakwani, A. A., Dennett, M., Jatoi, W. A., \& Channa, S. A. (2012). Assessment of wheat cultivars for drought tolerance via osmotic stress imposed at early seedling growth stages. Journal of Agricultural Research, 50(3), 299-310. Retrieved from http://www.jar.com.pk/curntissu\%20(2).php?p=547

Bano, A., Ullah, F., \& Nosheen, A. (2012). Role of abscisic acid and drought stress on the activities of antioxidant enzymes in wheat. Plant Soil Environ., 58(4), 181-185. Retrieved from http://www.agriculturejournals.cz/publicFiles/63008.pdf

Bayoumi, T., Eid, M. H., \& Metwali, E. (2008). Application of physiological and biochemical indices as a screening technique for drought tolerance in wheat genotypes. African Journal of Biotechnology, 7(14), 2341-2352. Retrieved from http://www.academicjournals.org/AJB

Biesaga-Kościelniak, J., Ostrowska, A., Filek, M., Dziurka, M., Waligórski, P., Mirek, M., \& Kościelniak, J. (2014). Evaluation of spring wheat (20 varieties) adaptation to soil drought during seedlings growth stage. Agriculture, 4(2), 96-112. https://doi.org/10.3390/agriculture4020096

Chachar, M., Chachar, N., Chachar, S., Chachar, Q., Mujtaba, S., \& Yousafzai, A. (2014). In-vitro screening technique for drought tolerance of wheat (Triticum aestivum L.) genotypes at early seedling stage. Journal of Agricultural Technology, 10(6), 1439-1450. Retrieved from http://www.ijat-aatsea.com/pdf/v10 n6_14_november/7_IJAT_10(6)_2014_M.H._Chachar-Crop\%20Physiology.pdf 
Chachar, Z., Chachar, N., Chachar, Q., Mujtaba, S., Chachar, G., \& Chachar, S. (2016). Identification of Drought Tolerant Wheat Genotypes Under Water Deficit Conditions. International Journal of Research GRANTHAALAYAH, 4(2), 206-2014. Retrieved from http://granthaalayah.com/Articles/Vol4Iss2/23 IJRG16_A02_84.pdf

Ciucă, M., Bănică, C., David, M., \& Săulescu, N. N. (2010). SSR markers associated with the capacity for osmotic adjustment in wheat (Triticum aestivum L.). Romanian Agricultural Research, 27(1), 1-5. Retrieved from https://www.researchgate.net/publication/268261853

Datta, J., Mondal, T., Banerjee, A., \& Mondal, N. (2011). Assessment of drought tolerance of selected wheat cultivars under laboratory condition. Journal of Agricultural Science and Technology, 7, 383-393. Retrieved from http://www.ijat-aatsea.com/pdf/April_v7_n2_11/16\%20IJAT2010_28FT.pdf

de Dorlodot, S., Forster, B., Pagès, L., Price, A., Tuberosa, R., \& Draye, X. (2007). Root system architecture: Opportunities and constraints for genetic improvement of crops. Trends in Plant Science, 12(10), 474-481. https://doi.org/10.1016/j.tplants.2007.08.012

Dhanda, S., Sethi, G., \& Behl, R. (2004). Indices of drought tolerance in wheat genotypes at early stages of plant growth. Journal of Agronomy and Crop Science, 190(1), 6-12. https://doi.org/10.1111/j.1439-037X. 2004.00592.x

El-Mohsen, A. A. A., El-Shafi, M. A., Gheith, E., \& Suleiman, H. (2015). Using Different Statistical Procedures for Evaluating Drought Tolerance Indices of Bread Wheat Genotypes. Advance in Agriculture and Biology, 4(1), 19-30.

El-Shafey, N. M., Hassaneen, R. A., Gabr, M. M., \& El-Sheihy, O. (2009). Pre-exposure to gamma rays alleviates the harmful effect of drought on the embryo-derived rice calli. Australian Journal of Crop Science, 3(5), 268. Retrieved from http://www.cropj.com/Nadia_3_5_2009_268_277.pdf

Ellis, R., \& Roberts, E. (1981). The quantification of ageing and survival in orthodox seeds. Seed Science and Technology (Netherlands), 9(2), 373-409. Retrieved from http://agris.fao.org/agris-search/search.do? recordID $=$ XE8182678

Farshadfar, E., Elyasi, P., \& Aghaee, M. (2012). In vitro selection for drought tolerance in common wheat (Triticum aestivum L) genotypes by mature embryo culture. American Journal Sciences Research, 48, 102-115.

Gholamin, R., \& Khayatnezhad, M. (2010). Effects of Polyethylene Glycol and NaCl Stress on Two Cultivars of Wheat Triticum durum at Germination and Early Seeding Stages. American-Eurasian Journal of Agricultural and Environmental Sciences, 9, 86-90. Retrieved from http://www.idosi.org/aejaes/ jaes9(1)/14.pdf

Golabadi, M., Arzani, A., \& Maibody, S. M. (2006). Assessment of drought tolerance in segregating populations in durum wheat. African Journal of Agricultural Research, 1(5), 162-171. Retrieved from http://citeseerx.ist.psu.edu/viewdoc/download?doi=10.1.1.128.5995\&rep=rep1\&type=pdf

Hamza, J. H. (2012). Seed Priming of Bread Wheat to Improve Germination Under Drought Stress. Iraqi Journal of Agricultural Sciences, 43(2), 100-107. Retrieved from http://repository.uobaghdad.edu.iq/ ArticleShow.aspx?ID=3655

Hassan, M. I., Mohamed, E. A., El-Rawy, M. A., \& Amein, K. A. (2016). Evaluating interspecific wheat hybrids based on heat and drought stress tolerance. Journal of Crop Science and Biotechnology, 19(1), 85-98. https://doi.org/10.1007/s12892-015-0085-x

Iqbal, N., \& Ashraf, M. Y. (2006). Does seed treatment with glycinebetaine improve germination rate and seedling growth of sunflower (Helianthus annuus L.) under osmotic stress. Pakistan Journal of Botany, 38(5), 1641-1648. Retrieved from http://www.pakbs.org/pjbot/PDFs/38(5)/PJB38(5)1641.pdf

ISTA. (1993). International Rules for Seed Testing. Seed Science and Technology, 21, 1-288. Retrieved from http://trove.nla.gov.au/version/13460205

Jain, M., Mittal, M., \& Gadre, R. (2013). Effect of PEG-6000 imposed water deficit on chlorophyll metabolism in maize leaves. Journal of Stress Physiology \& Biochemistry, 9(3), 262-271. Retrieved from http://www.jspb.ru/issues/2013/N3/JSPB_2013_3_262-271.pdf 
Jogaiah, S., Govind, S. R., \& Tran, L.-S. P. (2013). Systems biology-based approaches toward understanding drought tolerance in food crops. Critical Reviews in Biotechnology, 33(1), 23-39. https://doi.org/10.3109/ 07388551.2012 .659174

Kader, M. (2005). A comparison of seed germination calculation formulae and the associated interpretation of resulting data. Journal and Proceeding of the Royal Society of New South Wales, 138, 65-75. Retrieved from http://royalsoc.org.au/images/pdf/journal/138_Kader.pdf

Kader, M., \& Jutzi, S. (2004). Effects of thermal and salt treatments during imbibition on germination and seedling growth of sorghum at $42 / 19{ }^{\circ} \mathrm{C}$. Journal of Agronomy and Crop Science, 190(1), 35-38. https://doi.org/10.1046/j.0931-2250.2003.00071.x

Khakwani, A. A., Dennett, M. D., \& Munir, M. (2011). Drought tolerance screening of wheat varieties by inducing water stress conditions. Songklanakarin J. Sci. Technol, 33(2), 135-142. Retrieved from http://www.thaiscience.info/journals/Article/SONG/10761800.pdf

Khan, M., Shabbir, G., Akram, Z., Shah, M., Ansar, M., Cheema, N., \& Iqbal, M. (2013). Character association studies of seedling traits in different wheat genotypes under moisture stress conditions. SABRAO Journal of Breeding and Genetics, 45(3), 458-467. Retrieved from http://www.sabrao.org/journals/vol45_3_dec2014/ SABRAO\%20J\%20Breed\%20Genet\%2045(3)\%20458-467\%20Khan.pdf

Kim, Y.-J., Yun, S.-J., Park, H.-K., \& Park, M.-S. (2001). A Simple Method of Seedling Screening for Drought Tolerance in Soybean. Korean Journal of Crop Science, 46(4), 284-288. Retrieved from http://ocean.kisti.re.kr/downfile/volume/kscs/JMHHBK/2001/v46n4/JMHHBK_2001_v46n4_284.pdf

Kulkarni, M., \& Deshpande, U. (2005). In vitro screening of tomato genotypes for drought resistance using polyethylene glycol (PEG). Vegetable Science, 32(1), 11-14. Retrieved from http://www.ajol.info/ index.php/ajb/article/viewFile/56885/45294

Manoj, K., \& Uday, D. (2007). In vitro screening of tomato genotypes for drought resistance using polyethylene glycol. African Journal of Biotechnology, 6(6), 691-696. Retrieved from https://www.researchgate.net/ publication/27797690

Marmar, A., Baenziger, S., Dweikat, I., \& El Hussein, A. A. (2013). Preliminary screening for water stress tolerance and genetic diversity in wheat (Triticum aestivum L.) cultivars from Sudan. Journal of Genetic Engineering and Biotechnology, 11(2), 87-94. https://doi.org/10.1016/j.jgeb.2013.08.004

Ming, D., Pei, Z., Naeem, M., Gong, H., \& Zhou, W. (2012). Silicon alleviates PEG-induced water-deficit stress in upland rice seedlings by enhancing osmotic adjustment. Journal of Agronomy and Crop Science, 198(1), 14-26. https://doi.org/10.1111/j.1439-037X.2011.00486.x

Moayedi, A. A., Boyce, A. N., Barakba, S. S., \& Ghodsi, M. (2009). The Effects of Different Levels of Osmotic Stress on Germination and Seedling Growth in Promising Durum Wheat Genotypes. Middle Eastern and Russian Journal of Plant Science and Biotechnology, 3(1), 10-14. Retrieved from http://www.globalscience books.info/Online/GSBOnline/images/0906/MERJPSB_3(SI1)/MERJPSB_3(SI1)10-14o.pdf

Mohammadi, N., \& Mojaddam, M. (2014). The Effect of Water Deficit Stress on Germination Components of Grain Sorghum Cultivars. Indian Journal of Fundamental and Applied Life Sciences, 4(4), 289-291. Retrieved from http://www.cibtech.org/J-LIFE-SCIENCES/PUBLICATIONS/2014/Vol-4-No-4/JLS-043046-MANI-EFFECT-CULTIVARS.pdf

Mollasadeghi, V., Ghanifathi, T., Masoumzadeh, B., \& Aghahasanbeyglo, A. A. (2014). Bread wheat tolerance against drought at early growth stages and grain filling period. Applied mathematics in Engineering, Management and Technology, 2(2), 50-59. Retrieved from http://amiemt-journal.com/test/vol2-2/7.pdf

Moucheshi, A., Heidari, B., \& Assad, M. (2012). Alleviation of drought stress effects on wheat using arbuscular mycorrhizal symbiosis. International Journal of AgriScience, 2(1), 35-47. Retrieved from http://shirazu.ac.ir/dro/sites/dro/files/droPaG3Heydari-10.pdf

Mujtaba, S. M., Summiya, F., Khan, M. A., Mumtaz, A., \& Barakat, K. (2016). Physiological Studies on Six Wheat (Triticum aestivum L.) Genotypes for Drought Stress Tolerance at Seedling Stage. Agricultural Research \& Technology: Open Access Journal, 1(2), 1-6.

Noorka, I. R., \& Khaliq, I. (2007). An efficient technique for screening wheat (Triticum aestivum L.) germplasm for drought tolerance. Pakistan Journal of Botany, 39(5), 1539-1546. Retrieved from http://www.pakbs.org/ pjbot/PDFs/39(5)/PJB39(5)1539.pdf 
Placido, D. F., Campbell, M. T., Folsom, J. J., Cui, X., Kruger, G. R., Baenziger, P. S., \& Walia, H. (2013). Introgression of novel traits from a wild wheat relative improves drought adaptation in wheat. Plant Physiology, 161(4), 1806-1819. https://doi.org/10.1104/pp.113.214262

Qayyum, A., Razzaq, A., Ahmad, M., \& Jenks, M. A. (2011). Water stress causes differential effects on germination indices, total soluble sugar and proline content in wheat (Triticum aestivum L.) genotypes. African Journal of Biotechnology, 10(64), 14038-14045. https://doi.org/10.5897/AJB11.2220

Sani, D. O., \& Boureima, M. M. (2015). Effect of polyethylene glycol (PEG) 6000 on germination and seedling growth of pearl millet [Pennisetum glaucum (L.) R. Br.] and LD50 for in vitro screening for drought tolerance. African Journal of Biotechnology, 13(37), 3742-3747.

Sayar, R., Khemira, H., Kameli, A., \& Mosbahi, M. (2008). Physiological tests as predictive appreciation for drought tolerance in durum wheat (Triticum durum Desf.). Agronomy Research, 6(1), 79-90. Retrieved from http://agronomy.emu.ee/vol061/p6108.pdf

Van den Berg, L., \& Zeng, Y. (2006). Response of South African indigenous grass species to drought stress induced by polyethylene glycol (PEG) 6000. South African Journal of Botany, 72(2), 284-286. https://doi.org/10.1016/j.sajb.2005.07.006

Xinqing, S., Kun, W., Shi-Kui, D., Xiao-Xia, H., \& Mu-Yi, K. (2006). Regionalisation of suitable herbages for grassland reconstruction in agro-pastoral transition zone of northern China. New Zealand Journal of Agricultural Research, 49(1), 73-84. https://doi.org/10.1080/00288233.2006.9513696

Zare', S., Tavili, A., \& Shahbazi, R. (2010). The effect of different levels of salicylic acid on the improvement of germination components in berry plant under salinity and drought stress. Journal of Range and Watershed, Iranian Journal of Natural Resources, 3(1), 29-39.

Zhu, J., Kang, H., Tan, H., \& Xu, M. (2006). Effects of drought stresses induced by polyethylene glycol on germination of Pinus sylvestris var. mongolica seeds from natural and plantation forests on sandy land. Journal of Forest Research, 11(5), 319-328. https://doi.org/10.1007/s10310-006-0214-y

\section{Copyrights}

Copyright for this article is retained by the author(s), with first publication rights granted to the journal.

This is an open-access article distributed under the terms and conditions of the Creative Commons Attribution license (http://creativecommons.org/licenses/by/4.0/). 